\section{Meeting seeks to} rally support for
research projects

Vienna and Moscow. The United States hopes to obtain wider support at next week's G-7 meeting on nuclear safety in Moscow (see right) for a plan to provide $\$ 3.3$ million to set up a Chernobyl nuclear research centre to study nuclear safety and related issues.

Last month, the US Department of Energy and the Ukrainian ministry of environment signed a joint statement of intent to implement the programme. Both sides hope for additional investment from other countries.

Research is intended to focus primarily on how to increase the safety of nuclear reactors, how to implement appropriate decontamination programmes, and the development of systems of emergency planning in the event of any future nuclear accident.

The G-7 'nuclear summit' will also be asked to support a number of programmes discussed earlier this month by participants at an international seminar on methods of detecting nuclear and other explosive materials. These include programmes on securing the safety and preservation of nuclear and radioactive materials, preventing nuclear terrorism and cleaning up territories polluted by explosives.

The first international seminar on nuclear-physical methods of detection of hidden explosives and fissionable materials was held earlier this month in Obninsk, a town near Moscow where the first Soviet nuclear reactor was built. It was organized by the Russian Ministry of Atomic Energy, the International Scientific-Technological Centre and the Argonne National Laboratory in Illinois, United States.

The meeting was addressed by Vladimir Mikhailov, Russia's minister for atomic energy, who welcomed it as "the first open meeting of the scientists and engineers belonging to the formerly strictly secret field of research". He added that there was an "urgent necessity" to prevent the danger of nuclear terrorism and smuggling.

The Russian and foreign (primarily American) participants at the seminar discussed the theoretical and practical models of devices able to detect radioactive materials. The development of such devices is seen as one way of redirecting the efforts of highly qualified researchers and engineers previously engaged in development of nuclear weapons to the solving of peaceful tasks. Alison Abbott \& Carl Levitin

\title{
Politics dampens summit on Chernobyl's anniversary
}

Washington. World leaders are gathering in Moscow this weekend (19-20 April) for the first-ever summit devoted to nuclear safety issues, amid low expectations of tangible results and a strong suspicion that the summit is chiefly intended to bolster the re-election chances of Boris Yeltsin, the president of Russia.

Leaders of the seven largest capitalist economies (G-7) are meeting in Moscow with Yeltsin and senior officials of other states of the former Soviet Union (FSU) to discuss the safe operation of nuclear power plants and the secure handling of nuclear weapons materials. The meeting is timed to coincide with the tenth anniversary of the nuclear accident at Chernobyl in the Ukraine.

"I won't be disappointed, because I'm not expecting much," says Frank von Hippel, a physicist and nuclear non-proliferation expert who is a former senior official in the Clinton administration. Hippel will travel to Moscow with an independent task force that intends to press the leaders for drastic action to improve nuclear safety and security.

The so-called International Expert Task Force for the summit - a group of 46 prominent environmentalists and scientists, co-chaired by Alexei Yablokov of the Center for Russian Environmental Policy in Moscow and Tom Cochran of the Natural Resources Defence Council (NRDC) in Washington DC - is calling on the FSU states to earmark a number of dangerous nuclear power stations for shutdown over the next ten years, and on G-7 to set up a \$10-billion "revolving fund" to support nonnuclear energy sources to replace them.

According to US officials, however, there is no chance of the summit agreeing on anything so ambitious. Instead, it will seek to cement the more incremental approach currently being undertaken to nuclear safety and security issues.

The communiqué issued at the end of the meeting will probably express continued support from the G-7 for training and regulation at nuclear plants in the FSU, the officials said. It may also pledge backing for a study on the economics of decommissioning some nuclear plants, and the construction of a small demonstrator plant for the disposal of plutonium, the officials said.

In addition, Russia may be persuaded to join new negotiations on how to implement an existing agreement on the exchange of classified information about the status of its nuclear weapons materials.

The G-7 countries are in no position to tell the FSU states to close reactors. Indeed

\author{
IMAGE \\ UNAVAILABLE \\ FOR COPYRIGHT \\ REASONS
}

none have been shut since the Chernobyl accident, despite allegations that many are intrinsically unsafe. But G-7 countries hope that an outside study could persuade the states that decommissioning is the most economically viable option in some cases.

Kristen Suokko, associate director of international nuclear safety at the US Department of Energy, said that the summit would "provide an impetus" to existing efforts to improve reactor safety. These include US $\$ 180$ million spent by the United States so far on more than 170 separate projects, ranging from system upgrades to training schemes, under a programme managed by the Pacific Northwest National Laboratory in Washington state.

But some environmentalists have already written off the summit as a missed opportunity. Christopher Flavin, a nuclear power analyst at the Worldwatch Institute in Washington DC, says that it will pursue "a very mixed and confused agenda, underlying a desire to prop up" the nuclear industry in the FSU "while the whole thing is meant to prop up Yeltsin" in his bid for re-election. "The results will not really merit a summit," he predicts, adding that they could have been achieved "at a much lower level".

Colin Macilwain

\section{Indian opposition 'will}

New Delhi. The conservative Bharatiya Janata Party (BJP) of India, the major opposition to the ruling Congress party, has said that if it comes to office through next month's general elections it will hasten the deployment of the indigenous intermediaterange ballistic missile Agni, as well as reviewing India's nuclear policy and increasing funding for research in defence and security related areas.

The BJP's election manifesto says the party's main goal would be to take corrective actions on the Congress government's policies which, it says, have put the country's security in peril. The Congress govern- 